\title{
Wykaz publikacji ks. Tomasza Kaczmarka
}

\section{Opracowania przygotowane w Watykańskiej Kongregacji Spraw Kanonizacyjnych (o charakterze źródeł prawa kanonizacyjnego):}

Positio super martyrio Michaelis Kozal, Roma 1986, ss. 495 (współautorstwo).

Positio super martyrio Antonii Juliani Nowowiejski episcopi, Henrici Kaczorowski et Aniceti Kopliński sacerdotum, Mariae Annae Biernacka laicae et CIII Sociorum:

t. 1: Introductio generalis, Roma 1997, ss. 260;

t. 2: Disquisitiones de vita, virtutibus, martyrio et fama martyrii, Roma 1997, ss. 917;

t. 3/1: Summaria de CVII Servis Dei (1-60), Roma 1996, ss. 1035;

t. 3/2: Summaria de CVII Servis Dei (61-107), Roma 1996, ss. 1036-2238.

Positio super martyrio Servi Dei Georgii Popiełuszko in odium fidei, uti fertur, interfecti, Roma 2008, ss. 1170.

\section{Książki}

Sacramentum Christi nell'insegnamento di s. Cipriano, Roma 1983, ss. 78.

Sługa Boży Biskup Michał Kozal, Włocławek 1987, ss. 48.

Beato Michat Kozal, Arzignano 1988, ss. 40.

Męczennicy za wiarę 1939-1945, Warszawa 1996, ss. 488 (redakcja i współautorstwo).

Męczennicy za wiarę 1939-1945. Słudzy Boży z Diecezji Włocławskiej, Warszawa 1998, Ss. 158.

Męczennicy za wiare 1939-1945. Ks. Henryk Hlebowicz, Warszawa 1998, ss. 62. 
Die Märtyrer für den Glauben 1939-1945, Olsztyn 1999, ss. 46.

Luci nelle tenebre. I 108 martiri della Chiesa in Polonia 1939-1945, Warszawa 1999, ss. 134

(współautor: F. Peloso); tł. Lights in the darkness, Warszawa - Marki 2000, ss. 208.

Światła w ciemności. Męczennicy 1939-1945, Włocławek 2000, ss. 150.

Sanktuarium licheńskie i Męczennicy, Warszawa 2001, ss. 198.

Bp Michał Kozal „Mistrz Męczenników”, Włocławek 2001, ss. 128.

„Seges Ecclesiae”. Eklezjalny wymiar męczeństwa w nauczaniu św. Augustyna, Toruń 2010, ss. 246.

Świadkowie wiary, Włocławek 2012, ss. 260.

\section{Artykuły}

Moc znaku krzyża. Uwagi z teologii III w., VoxP 6-7 (1984) s. 160-170.

La cattedrale di Włocławek, w: Repertorio delle cattedrali gotiche, red. E. Brivio, Milano 1986, t. 2, s. 715-722.

„, Tajemnica kielicha Pańskiego” wg Listu 63 św. Cypriana, w: Pokarm nieśmiertelnoś$c i$, red. W. Myszor - E. Stanula, Katowice 1987, s. 144-156.

X Międzynarodowy Kongres Studiów Patrystycznych w Oksfordzie, VoxP 12-13 (1987) s. 514-517.

Biskup Michat Kozal - sylwetka duchowa, AK 472 (1987) s. 513-524.

Próby ratowania bpa Kozala przez Stolicę Apostolska, AK 472 (1987) s. 538-544.

Świat rzymski w ocenie św. Cypriana, w: Chrześcijanie a życie publiczne w Cesarstwie Rzymskim III-IV w., red. J. Śrutwa, Lublin 1988, s. 63-70.

Perykopa Dz 6, 1-6 w interpretacji patrystycznej, VoxP 17 (1989) s. 599-604.

Ryty chrzcielne jako naśladowanie tajemnic paschalnych wedtug II katechezy mistagogicznej Cyryla Jerozolimskiego, VoxP 18 (1990) s. 82-88.

Los sprawiedliwych Starego Testamentu po śmierci wedtug świadectw I-II w., VoxP 19 (1990) s. 589-597.

Ideały życia pustelniczego w IV w., w: Wczesnochrześcijańska asceza, red. F. Drączkowski - J. Pałucki, Lublin 1993, s. 59-71. 
Proces kanonizacyjny męczenników, którym przewodzi bł. Michał Kozal, w: Elementy prawne świętości kanonizowanej wedtug ustawodawstwa Jana Pawła II, red. H. Misztal, Lublin 1993, s. 174-182.

Refleksje nad sensem dziejów świata w nauczaniu św. Augustyna, w: W stużbie Kościołowi i nauce. Księga pamiątkowa ku czci Ks. Prof. Stanisława Olejnika w 80. rocznice urodzin, red. J. Bagrowicz, Włocławek 1994, s. 90-95.

Proces zabójców duszpasterzy z Osięcin 6-11.VI.1940: sprawcy i motywacje, „Saeculum Christianum" 2 (1995) s. 181-192.

Stuga Boży Biskup Wojciech Owczarek - przestanie o świętości, „Kronika Diecezji Włocławskiej” 80 (1997) s. 400-410.

Św. Józef w nauczaniu Ojców Kościoła. Idee przewodnie, SWł 1 (1998) s. 61-70.

Organizacja dzieł charytatywnych Kościoła w Kartaginie pod kierunkiem św. Cypriana, SWł 2 (1999) s. 125-131.

Z czym Kościót w Polsce wchodzi w Trzecie Tysiąclecie? Przesłanie męczenników z okresu II wojny światowej, w: „, Te Deum laudamus”. Program duszpasterski na Wielki Jubileusz Roku 2000, red. E. Szczotok - R. Kempny - A. Liskowacka, Katowice 1999, s. 293-310.

„Descendit ad inferos”: prawda zbawcza przekazywana $w$ szacie języka starożytnego, SWł 3 (2000) s. 111-122.

Taktyka szatana wobec Kościoła wg św. Cypriana, w: Demonologia w nauce Ojców Kościoła, red. H. Pietras, Kraków 2000, s. 39-54.

Nazizm hitlerowski jako „prześladowca wiary”, AK 548 (2000) s. 29-43.

Obraz świadectw 108 błogosławionych męczenników, AK 548 (2000) s. 44-58.

Bibliografia 108 błogosławionych męczenników, AK 549 (2000) s. 258-277.

Nowowiejski Antonio Giuliano, vescovo; Kaczorowski Enrico e Koplinski Adalberto (Aniceto), sacerdoti; Bernacka Marianna, laica e 104 compagni martiri, beati, w: Biblioteca Sanctorum. Seconda appendice, red. F. Caraffa, Roma 2000, s. 1010-1026.

Tematyka cierpienia w nauczaniu Ojców Kościoła, AK 555 (2001) s. 227-247.

Tajemnica wcielenia w nauczaniu Leona Wielkiego, VoxP 38-39 (2001) s. 323-331.

Chrystus i męczennik wedlug świadectw patrystycznych z trzech pierwszych wieków, SWł 4 (2001) s. 144-153. 
Przestanie Błogosławionych Męczenników z okresu II wojny, w: Świadectwo wiary aż po męczeństwo w Zakonach Franciszkańskich, Kraków 2001, s. 77-94.

Symbolika chrzcielna w nauczaniu Kościoła starożytnego, SWł 5 (2002) s. 137-149.

Nowi męczennicy, w: W Panu złożyłem nadzieję. Księga pamiątkowa ku czci Biskupa Czesława Lewandowskiego w 80. rocznice urodzin, red. R. Andrzejewski, Włocławek 2002, s. 129-147.

Zło o charakterze osobowym - Szatan w refleksji teologicznej i doświadczeniu Kościoła, SWł 6 (2003) s. 241-254.

Fenomen życia pustelniczego w Kościele starożytnym, w: Edukacja - Kultura - Teologia. Studia ofiarowane Ks. Prof. Jerzemu Bagrowiczowi, red. K. Konecki - I. Werbiński, Toruń 2003, s. 786-804.

„Ecclesia sponsa Christi” w nauczaniu św. Cypriana, w: Prawda i miłość. Księga pamiatkowa ku czci Bp. Bronisława Dembowskiego na złoty jubileusz kapłaństwa, red. R. Andrzejewski, Włocławek 2003, s. 426-434.

Organizacja $i$ działalność Studium Teologii we Włocławku w latach 1992-1994, w: Studium Teologii we Włocławku 1992-2002, red. T. Lewandowski - M. Łaszczyk - K. Skoczylas, Włocławek 2003, s. 101-114.

Stuga Boży biskup Wojciech Owczarek: przesłanie duchowe, SWł 7 (2004) s. 385-396.

Pytania chrześcijan drugiego stulecia o człowieka, TiCz 3 (2004) s. 19-37.

Jan Paweł II wobec świadectwa ks. Jerzego Popiełuszki, AK 574 (2004) s. 494-507.

Świadkowie wiary dwudziestego stulecia przywołani przez Jana Pawła II, w: Jan Pawet II apostoł prawdy. Księga pamiątkowa ku czci i pamięci Ojca Świętego Jana Pawła II, red. J. Kędzierski, Włocławek 2005, s. 157-169.

Duch egzegezy patrystycznej, TiCz 5 (2005) s. 79-98.

Symbol Apostolski jako formuła wiary Kościoła, w: Ekumenizm Teologia Kultura. Księga pamiatkowa dedykowana Księdzu Profesorowi Wojciechowi Hancowi z okazji 65. rocznicy urodzin, red. K. Konecki - Z. Pawlak - K. Rulka, Włocławek 2006, s. $359-373$.

Wyznania wiary starożytnego Kościoła, SWł 9 (2006) s. 93-107.

Świadkowie wiary i dzieło budowy cywilizacji chrześcijańskiej. 108 Bt. Męczenników z czasu II wojny światowej, w: Władysław Goral-Błogosławiony biskup i męczennik (1898-1945), red. C. Taracha, Lublin 2006, s. 213-232. 
Przesłanie soteriologiczne $w$ Kościele okresu poapostolskiego, $\mathrm{TiCz}$ 7-8 (2006) s. $107-122$.

Sługa Boży ks. Jerzy Popiełuszko, „Miesięcznik Pasterski Płocki” 10 (2006) s. 455-459.

Godność człowieka w Chrystusie i droga jej dopetnienia wedtug świętego Ireneusza, „Teologia Patrystyczna” 3 (2006) s. 129-142.

Dulny Tadeusz, w: Włocławski Słownik Biograficzny, t. 4, red. S. Kunikowski, Włocławek 2006, s. 27-29.

Kostkowski Bronisław, w: Włocławski Słownik Biograficzny, t. 4, red. S. Kunikowski, Włocławek 2006, s. 63-64.

Na stużbie miłości Kościoła. Uwagi o postudze pasterskiej św. Augustyna, w: Śladami świętych. Księga pamiątkowa ku czci Gabriela Jana Bartoszewskiego OFM Cap, red. A. Derdziuk, Lublin 2007, s. 321-332.

Świętość kanonizowana, AK 591 (2007) s. 227-240.

Wkład ks. Stanisława Librowskiego w proces beatyfikacyjny bpa Michała Kozala, SW1 10 (2007) s. 85-95.

Św. Augustyn - ,, Sermo de disciplina christiana”, VoxP 52 (2008) s. 373-383.

Jan Pawet II i promocja męczeństwa chrześcijańskiego, w: Jan Pawet II orędownik prawdy i nadziei, red. M. Włosiński, Włocławek 2008, s. 93-102.

„Caritas” jako kryterium przynależności do Kościoła. Aspekty eklezjologii św. Augustyna, SWł 11 (2008) s. 132-142.

Błogosławiony Michał Kozal, biskup męczennik, „Miesięcznik” 92/6 (2009) s. 687-719.

Ksiadz Jerzy Popietuszko - świadek prawdy, „Pietas et Studium” 2 (2009) s. 457-468.

Ksiąd Jerzy Popietuszko - duchowa wielkość, SWł 12 (2009) s. 81-91.

Owocowanie świętości kapłańskiej wczoraj i dziś, „Miesięcznik” 92/12 (2009) s. 1276-1292.

Świadectwo kapłana męczennika, „Miesięcznik” 93/10 (2010) s. 963-981.

Obyczajowość matżeńska $w$ Kościele afrykańskim $w$ czasach św. Augustyna, SWł 13 (2011) s. 61-70.

Problematyka Antychrysta, „Miesięcznik” 94/2 (2011) s. 205-230. 
$\bar{S}$ w. Augustyn - czas odejścia, w: „Veritas cum caritate - intellegentia cum amore”, Księga jubileuszowa bp A. Suskiego, red. Cz. Rychlicki - I. Werbiński, Toruń 2011, s. 213-223.

„,Mysterium lunae” w eklezjologii starożytnego Kościoła, TiCz 17 (2011) s. 43-59.

108 polskich męczenników II wojny światowej, „Świętość Kanonizowana” 8 (2012) s. 85-106.

Proces beatyfikacyjny bt. Ks. Jerzego Popietuszki, męczennika reżimu komunistycznego schytku PRL, „Świętość Kanonizowana” 8 (2012) s. 155-178.

Diakonia męczenników w ujęciu św. Augustyna, w: Świadectwo w stużbie ewangelizacji, Lublin 2012, s. 55-80.

Kult męczenników oraz cuda za ich wstawiennictwem wedtug św. Augustyna, SWł 14 (2012) s. 77-87.

Augustyn do braci „ex parte Donati”, w: Ortodoksja, herezja, schizma w Kościele starożytnym, red. F. Drączkowski et al., Lublin 2012, s. 133-144.

„Semen sanguinis martyrum, seges Ecclesiae” - il mistero della crescita della Chiesa secondo sant'Agostino, TiCz 19 (2012) s. 101-114.

Augustyn ekumenista, SWł 15 (2013) s. 23-36.

Katechizm biblijny Kościoła kartagińskiego, „Polonia Sacra” 33 (2013) s. 17-42.

Il termine «sacramentum» nell'accezione cristiana. La testimonianza di s. Cipriano, TiCz 21 (2013) s. 69-83.

Dylemat chrześcijanina żotnierza w świetle „,De corona” Tertuliana, SWł 16 (2014) s. $147-156$.

Racjonalny charakter wiary wedtug św. Augustyna, VoxP 61 (2014) s. 427-440.

Św. Augustyn: zmaganie się nad słowem o tajemnicy Trójcy Świętej, AK 636 (2015) s. $345-355$.

Odnalezienie relikwii św. Szczepana „otworzeniem bramy łaskawości Boga”, SWł 17 (2015) s. 133-144.

Systemy totalitarne dwudziestego stulecia jako prześladowca Kościoła, SWł 19 (2017) s. 439-454. 
Bt. Michat Kozal, Biskup Męczennik. Owocowanie świętości, w: Ubi episcopus ibi ecclesia. Jubileusz postugi Ks. Biskupa Wiesława Alojzego Meringa w Diecezji Włocławskiej, red. A. Tomalak, Włocławek 2019, s. 91-104.

Męczennicy z Wyższego Seminarium Duchownego we Włocławku, w: 450 lat „Almae Matris Vladislaviensis”. Księga jubileuszowa, red. J. Szymański, Włocławek 2019, s. $15-48$.

Język łaciński w Wyższym Seminarium Duchownym we Włocławku. Uwagi wykładowcy, w: 450 lat „Almae Matris Vladislaviensis”. Księga jubileuszowa, red. J. Szymański, Włocławek 2019, s. 201-204.

\section{Recenzje}

J. Daniélou, Święci «poganie» Starego Testamentu. Pisma wybrane (tł. Sz. Fedorowicz), Kraków 2013, ss. 100 - recenzja: TCzł 27 (2014) 249-252.

„Apokryfy Nowego Testamentu (red. M. Starowieyski): t. 1 (część 1-2) Ewangelie apokryficzne, Kraków 2003; t. 2 Listy i Apokalipsy chrześcijańskie, Kraków 2002; t. 3 (część 1-2) Apostołowie, Kraków 2007; t. 4 Apokryfy syryjskie, Kraków 2011” - recenzja: AK 629 (2014) s. 192-196.

\section{Prace translatorskie}

\section{na język włoski}

W. Frątczak, Biskup Michał Kozal: życie, męczeństwo, kult (Vescovo Michele Kozal: vita, martirio, fama di santità), Roma 1985, ss. 130.

La dimensione ecumenica dei sacramenti dell'iniziazione cristiana alla luce dei dialoghi dottrinali-Riassunto, w: Ekumeniczny wymiar sakramentów chrześcijańskiej inicjacji. Studium ekumeniczne, red. W. Hanc, Włocławek 2003, s. 889-898; 959-967.

\section{z języka włoskiego}

Documenti di Santa Sede riguardo alla beatificazione di Michat Kozal vescovo e martire, AK 473 (1987) s. 53-62; 67-70.

E. Pierini, Mille anni del pensiero cristiano, t. 1, Roma 1988, s. 186-253. 


\section{Inne publikacje}

Ku beatyfikacji Męczenników. Biuletyn Postulacji sprawy beatyfikacji 108 Męczenników

Kościoła w Polsce z okresu II wojny, t. 1-7, Włocławek 1998-1999.

Redakcja serii wydawniczej Męczennicy 1939-1945, Włocławek 2000-2001 (wydane

72 zeszyty), autorstwo 15 zeszytów w tejże serii:

z. 22 - Ks. Piotr Dańkowski;

z. 33 - Bp Leon Wetmański;

z. 45 - Ks. Roman Sitko;

z. 48 - Ks. Michał Oziębłowski;

z. 50 - Ks. Michał Woźniak;

z. 51 - Al. Tadeusz Dulny;

z. 52 - Ks. Edward Grzymała;

z. 53 - Ks. Henryk Hlebowicz;

z. 54 - Ks. Dominik Jędrzejewski;

z. 55 - Ks. Henryk Kaczorowski;

z. 56 - Al. Bronisław Kostkowski;

z. 57 - Ks. Józef Kurzawa;

z. 58 - Ks. Wincenty Matuszewski;

z. 59 - Ks. Leon Nowakowski;

z. 60 - Ks. Józef Straszewski.

Biskup Wojciech Owczarek - „,Muszę zostać świętym”, Włocławek 2004, ss. 46.

Zagrożenia wiary ze strony ezoteryzmu/okultyzmu, Włocławek 2006, ss. 16 (wydanie ponawiane czterokrotnie, łączny nakład 55 tys. egzemplarzy).

T. Kaczmarek - H. Pietras, Starożytny Kościót. Tablica chronologiczna. Słownik osób i dziet, Kraków 2006.

Redakcja i współautorstwo Biuletynu Postulacji sprawy beatyfikacji ks. Jerzego Popiełuszki: Stuga Boży Ks. Jerzy Popiełuszko 1947-1984, t. 1-6, Warszawa 2009-2010. 


\section{$\mathrm{Z}$ recenzji związanych $\mathrm{z}$ uzyskaniem $\mathrm{w} 2008$ roku nagrody drugiego stopnia rektora UMK w Toruniu}

Rev. Prof. José Luis Gutiérrez, profesor prawa kanonicznego na Uniwersytecie „Santa Croce” w Rzymie, relator Kongregacji Spraw Kanonizacyjnych:

Główna wartość dzieła leży w tym, że ukazuje ono zastosowanie najwłaściwszej metody naukowej, łączonej harmonijnie z rygorystycznym przestrzeganiem linearności i przejrzystości przedstawianych problemów, co pozwala na bezstronne podprowadzenie lektora do konkluzji, jakie ma sam wyprowadzić. Oceniam przeto omawianą Positio jako ważny wkład, ubogacenie dorobku literatury z zakresu problematyki spraw kanonizacyjnych, która może być oparciem do redagowania innych Positiones, jak i do rozpraw z dziedziny Prawa kanonizacyjnego.

Ks. prof. dr hab. Henryk Misztal, KUL:

Bardzo bogaty dorobek naukowy o charakterze międzynarodowym, a w szczególności przedstawiana Positio, dają podstawę do uzasadnionego twierdzenia, iż ks. dr Tomasz Kaczmarek wniósł nieprzeciętny wkład naukowy ze strony polskiej teologii i kanonistyki do ogólnoświatowej literatury przedmiotu. Sam fakt, że omawiana praca została uznana jako oficjalny dokument Kongregacji, promuje nie tylko osobę autora, ale także naukę polską zagranicą. [...] Positio opracowana $\mathrm{w}$ języku włoskim nie przejdzie niezauważona $\mathrm{w}$ literaturze światowej i będzie stanowić doskonałe źródło na temat stosunków państwo - Kościół w okresie totalitaryzmu komunistycznego nie tylko dla historyków, ale także znawców prawa wyznaniowego. Taką zresztą funkcję już spełniło czterotomowe opracowanie tegoż samego autora, przygotowane wcześniej w Kongregacji Spraw Kanonizacyjnych w latach 1994-1998 (dotyczące 108 Męczenników za wiarę z Kościoła w Polsce z czasu II wojny), poświęcone problematyce konfrontacji narodowego socjalizmu III Rzeszy z kulturą chrześcijańską w Polsce. 